\title{
Local Wisdom in the Adding-dinging Ritual of the Tenro Community in Selayar Islands Regency, South Sulawesi
}

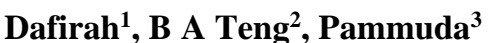 \\ \{1'dafirah_asad@yahoo.com, ${ }^{2}$ baharakkase@gmail.com, ${ }^{3}$ beppalu@yahoo.co.id \} \\ ${ }^{1,2,3}$ Hasanuddin University Makasar, Indonesia
}

\begin{abstract}
One of the cultural heritages in the form of oral tradition that still survives until now is addinging-dinging rituals. This ritual was found in South Sulawesi, precisely in Selayar Islands Regency. Regularly the Selayar people in Tenro perform this ritual. The implementation has also been scheduled, i.e. every last Monday in Muharram. Despite its peak on Monday, the Tenro community has carried out several activities before as preparation for preparation. Various activities and devices used in this ritual are symbols that are born from the community itself. The symbol itself contains the meaning and value that can be created as a source of local wisdom. This research is qualitative research that uses several methods in data collection. In primary data collection, field research was carried out using recording and interview techniques. In addition to primary data, of course secondary data is also needed to better complement this research data. Based on the results of the meanings of the activities and devices used in this ritual, the local wisdom found is: appreciation to the ancestors; maintain survival, preserve the environment; strengthen a sense of solidarity; and strengthen the tradition of mutual cooperation.
\end{abstract}

Keywords: Local Wisdom, Ritual, Addinging Dinging

\section{INTRODUCTION}

Selayar Islands is one of the districts in South Sulawesi. This regency has its own uniqueness compared to other districts, which cannot be reached by land. To arrive in the Selayar Islands regency must be by sea or airway. In addition, the Selayar Islands Regency has many traditional cultures that still survive and are maintained until now. One of them is the addinging-dinging ritual that is routinely carried out every year by the Tenro community in Buki District.

Rituals in many ways are interpreted as religious ceremonies in a community [1]-[3]. The religion meant here is an understanding of religiosity including belief in magical or mystical powers. Rituals can also be interpreted as certain behaviours that are formal, carried out in a certain time differently, not just as a technical routine. Because the community believes that the rituals they perform are media to relate to ancestral spirits or with the creator. That is why addinginging-dinging rituals are neutralized even though they are not closed to visitors, as long as the visitors are able to adapt and respect their activities. Rituals according to Victor Tuner 
refer to actions that are based on religious beliefs about mystical powers and powers [4]. In carrying out actions related to rituals, the tools and equipment are not separated [5], [6].

Equipment used in addinging-dinging rituals in the form of objects that become symbols of hope or desire they are targeting in their lives. The symbols are rich in the meaning and value they contain. The excavation of the meaning and value contained is important as an effort to discover the local wisdom of the Tenro community.

During the ritual implementation, many tools and behaviours carried out by the Tenro community were in the form of symbols which they unconsciously created themselves. Geertz in a theory called symbolic interpretive theory suggests that symbols are objects, events, sounds, speech, or written forms that are given meaning by humans [7]. These symbols are collective agreements that they build conventionally [8], [9]. Furthermore, these symbols are interpreted based on the context of the Tenro community which became the forerunner of local wisdom.

Local wisdom is a cultural inheritance that exists in the community (traditional) and is inherited from the community concerned for generations. Local wisdom is knowledge, understanding, and habits that direct human life in people's lives, in the lives of ecological communities [10], [11]. In addition, local wisdom can be understood as local ideas that are wise, full of wisdom, good value, embedded and followed by members of the community [12]. Communities without being bound by laws or regulations but because of the encouragement of conscience will always be obedient to their local wisdom. Talking about local wisdom cannot be separated from indigenous people [13]-[15].

\section{RESEARCH METHOD}

Research is classified into qualitative research so that data, data analysis, and the results of the discussion are all in the form of words. Primary data is collected through field research using interview techniques, recording (images and audio). Interviews are conducted in depth using interview guidelines in the form of outlines of the problems needed from the informant. Informants were chosen from traditional leaders (ritual leaders), community leaders (priests and village heads), and owners of houses where ritual centres were conducted. Voice recording is done when interviews and rituals take place while audio-visual recording is done when the ritual takes place.

\section{RESULTS AND DISCUSSION}

\subsection{Ritual Procession}

The addinginging-dinging ritual is a ritual that is routinely carried out by the Tenro people every year in the Muharram of the Hijri year, precisely on the last Monday. This ritual was carried out by the Tenro community as well as the anniversary of the birth of the Tenro village. In its implementation the procession begins with the implementation of the anrajo-rajo tradition. Activities are pilgrimage activities to ancestral tombs or visiting sacred places. This activity starts on Friday, Saturday and Sunday. This activity was carried out by a group of mothers accompanied by drum beat. The group was led by a female figure by bringing offerings and incense as a medium to summon their ancestral spirits.

On Sunday afternoon the procession was carried out by taking holy water in an old well. This activity was also carried out by women as many as seven people, carrying bengki and one of them carrying incense. This group was also accompanied by the drumming of two boys. 
On the Sunday night the procession was continued with the making of holy water which was led directly by the traditional figure of a woman and a man. Bengki-bengki which is filled with water is then spelled by the two ritual leaders. But before being spelled out, there will be a addinging-dingig singing procession performed by seven adult women and one of them carrying incense. The seven women circled the bengki seven times while singing and accompanied by drum beat.

On Monday morning after the procession of anrajo-rajo, it continued with adding the singing that the community had taken place and followed by reading a prayer/mantra by the ritual leader. After that, the leader of the ritual slowly began to splash water and activities with each other, after the community is satisfied with watering each other, the procession ended by sitting together under the sambal tree eating together.

\subsection{Local Wisdom in Addinging-dinging Rituals:}

Based on the behaviour and objects they use in the ritual, the local wisdom found is: At each ritual activity is a presence or presence of incense and two pairs of drum. Incense smoke that is steaming is a medium of communication with the spirits of their ancestors. Likewise the existence of drum wasps in rituals, people expect their ancestors to be present in the midst of their liking. In addition, it was found that the offerings of fried rice from the side dishes which were placed on small plates as surrender to their ancestors. Local wisdom that can be taken from this symbol is appreciation to the ancestors. Appreciation to ancestors can be transformed into awards to parents. The young generation must and must be taught how to respect and respect parents.

In addition, this ritual is also a form of gratitude for all the pleasures they have had during the year. Also as an expression of hope that the future will be more successful in various businesses, more strengthened in terms of togetherness. These prayers and hopes were uttered by the ritual leaders, enlightening the implementation of mass showers.

An old well is kept clean because it is considered a sacred well where you will make holy water. Water is a source of primary needs for humans and wells are one source of springs beside the others. So that water and springs must be maintained because maintaining springs means maintaining survival.

All stages of ritual activities always involve the community not only in the Tenro region, including their neighbouring villages. The activity began when making a presentation (offerings) at the hamlet chief's house, followed by taking seven holy water women plus two drummer boys. Then at night the making of holy water also involves invitations from outside. Especially when carrying out the peaking adding-dinging ritual. And what's even more interesting is that at every ritual procession it will always end with a meal together. All of this is a symbol of the togetherness of the Tenro community. They unconsciously merge into a celebration without seeing differences in status and stratification because they are dominated by a sense of solidarity. A local wisdom deserves to be emulated and appreciated because with a strong sense of solidarity, division, hostility or dispute will decrease or decrease. This local wisdom is very important to be explored and socialized that togetherness is the most beautiful gift that is able to erase the traces of envy and revenge towards others. In the hustle and bustle of the nation in the millennium, it still needs to be fortified with local wisdom, especially strengthening in solidarity.

This ritual is basically carried out purely by the community so that all facilities and budgets come from the community as well. Although the last three years of the Selayar Islands regional 
government in this case the cultural office sometimes provided assistance in carrying out activities.

Apart from that, people who have carried out rituals continuously for tens, maybe even hundreds of years ago were accustomed to preparing everything in mutual cooperation and selfhelp. When eating with dozens of trays neatly arranged under the banyan tree is a voluntary contribution of each head of the household. Menu problems are not a problem because they are adjusted to the economic capacity of the family concerned; the most important thing is how they participate sincerely and intact in their rituals [16]. In addition, at the house of the gathered hamlet head the mothers are to involve themselves in preparing a meal menu when making holy water and when taking holy water. On the other hand, men jointly prepare folk games such as the establishment of swing poles and so on.

Regarding mutual cooperation, the Tenro community in a few days forgot the personal interests of those who generally cultivated (farmers). They focus on preparing for the ritual they will carry out.

\section{CONCLUSIONS}

Adding-dinging rituals include rituals that are rich in local wisdom. As stated earlier that local wisdom belongs to traditional/local communities. However, it is possible to transform it into millennial human life. The values in it are important and needed by this nation.

\section{ACKNOWLEDGEMENT}

The author did not forget to thank the Ministry of Research, Technology and Higher Education for facilitating this research. Also thanks to the Selayar Islands Regency Government, especially Buki Sub-District Head, Bontolempangan Village Head, Tenro Hamlet Chief, the Tenro Community as a whole who openly gave space and space to our team to conduct research.

\section{REFERENCES}

[1] K. Sintia, "Community Trust in Rituals Moving Rain in Tualang District, Siak Regency," JOM PHISIOP, vol. 4, no. 2, pp. 1-15, 2017.

[2] H. Salamon and H. E. Goldberg, "MYTH-RITUAL-SYMBOL," in A Companion to Folklore, West Sussex: Blackwell Publishing, 2012.

[3] A. L. Becker and K. Noone, Welsh Mythology and Folklore in Popular Culture: Essays on Adaptations in Literature, Film, Television, and Digital Media, vol. 33. Jefferson, North Carolina, and London: McFarland \& Company Inc. Publishers, 2011.

[4] D. Melita, "Obong Ritual as Death Ritual of Kalang People in Bumi Ayu Village, Weleri District, Kendal Regency," University of Semarang, 2015.

[5] F. N. Setiawan, M. A. Nurmansyah, R. Nufiarni, and S. V. Eka, "Manifestasi Kearifan Ekologis Dalam Ritual 'Karo' Dan 'Kasada': Sebuah Perspektif Ekokritik,' Atavisme, vol. 21, no. 2, p. 209, Dec. 2018.

[6] J. P. Millie, Splashed by The Saint: Ritual Reading and Islamic Sanctity in West Java. Leiden: Leiden University, 2006.

[7] P. Leonardo and R. Iksan, "Ritual of Tauh Dance in Kenduri SKO (Symbolic Interpretivism Study: Lolo Hilir Village Community)," Twelfth Year History and Culture Journal, vol. 1, no. June, pp. 49-59, 2018.

[8] R. F. Bendix and G. Hasan-Rokem, Eds., A Companion to Folklore. West Sussex: Wiley 
- Blackwell, 2012.

[9] F. A. De Caro, Folklore Recycled : Old Traditions in New Contexts. Jackson: University Press of Mississippi, 2013.

[10] D. F. Sari, "Local Wisdom of the Community in Preserving Batang Aie Lunang in Kenagarian Lunang in Lunang District, South Coastal District. Education Study Program STKIP PGRI West Sumatra.,” Jurnal Spasial, vol. 2, no. 1, 2015.

[11] Y. Primadesi, "Preserving of Information Value in Oral Tradition of Minangkabau society, West Sumatera, Indonesia," in In The 5th Rizal Library International Confrence, 2012.

[12] Sartini, "Exploring Local Archipelago Wisdom, A Philosophy Study," Journal of Philosophy, vol. 37, no. 2, 2004.

[13] P. Hijjang et al., "Puyakhabhu: Local Wisdom Values In Environmental Management At Sentani Indigenous Community In Jayapura Regency, Papua," International Journal of Arts \& Sciences, vol. 11, no. 1, pp. 59-66, 2018.

[14] A. Cunsolo Willox, S. L. Harper, and V. L. Edge, "Storytelling in a digital age: Digital storytelling as an emerging narrative method for preserving and promoting indigenous oral wisdom," Qualitative Research, 2013.

[15] V. Ganap, "Konsep Multikultural Dan Etnisitas Pribumi Dalam Penelitian Seni," Humaniora, vol. 24, no. 2, pp. 156-167, 2012.

[16] B.W. Setyawan and K. Saddhono, "Eret traditional ceremony as representation of spirit of mutual cooperation among coastal communities". Adv. Sci. Let. vol. 23 no.10, pp 9991-9992, 2017 